\title{
PENGARUH WAKTU DISTILASI MINYAK BIJI PALA (Myristica fragrans) DENGAN METODE DISTILASI UAP DAN IDENTIFIKASI KOMPONEN KIMIAWI
}

\author{
Rini Astuti ${ }^{1}$ \\ ${ }^{1}$ Laboratorium Pangan dan Gizi, Departemen Teknologi Pangan dan Hasil Pertanian \\ Fakultas Teknologi Pertanian, Universitas Gadjah Mada. email : rini gizi68@ugm.ac.id
}

\section{ABSTRAK}

Tanaman Pala (Myristica fragrans) adalah tanaman asli Indonesia. Indonesia merupakan negara pengekspor biji dan fuli terbesar di dunia. Biji Pala menghasilkan fixed oil 20-40\% yang terdiri dari asam miristat, trimiristin dan gliserida dari asam laurat, stearat dan palmitat. Dalam penelitian ini, lama waktu yang digunakan adalah 1 jam, 2 jam dan 3 jam. Deperoleh minyak $1 \mathrm{ml}, 1,5 \mathrm{ml}$ dan 1,8 $\mathrm{ml}$. Diperoleh kandungan minyak terbanyak pada lama distilasi 3 jam.Trimiristisin yang terkandung dalam biji pala mencapai 85\% dan dimanfaatkan pada industri kosmetik. Minyak atsiri dari biji pala diperoleh dengan metode distilasi uap dan dianalisis komponen kimia minyak atsiri dengan metode GC-MS. Dari hasil penelitian diperoleh minyak atsiri berwarna kuning jernih dan beraroma khas pala. Identifikasi komponen kimiawi dengan metode GC-MS menunjukkan minyak atsiri biji pala hasil isolasi mengandung Sabinene (42,76\%), a-Pinene (3,61\%), cyclobutane (15,01\%), $\beta$ Phelladrene (6,94\%); Gamma Terpinene (5,41\%), Terpinolene(1\%); Terpineol-4 (4,98\%), Safrene (4,12\%); a Phellandrene (3,32\%); Myristicin (0,95\%).Kesimpulannya lama waktu distilasi 3 jam mendapatkan hasil minyak biji pala terbanayak yaitu $1,8 \mathrm{ml}$.

Kata kunci: Biji Pala; minyak atsiri; distilasi uap; komposisi kimiawi; GC-MS.

\section{PENDAHULUAN}

Hasil tanaman Pala (Myristica fragrans) dikenal sebagai tanaman rempah yang memilikinilai ekonomis tinggi karena permintaan pasar yang tinggi di pasar internasional. Hasil tanaman pala yang dapat dimanfaatkan adalah buah pala. Buah pala terdiri dari daging buah $(77,8 \%)$, fuli $(4 \%)$, tempurung $(5,1 \%)$ dan biji $(13,1 \%)$. Bagian biji dan fuli dapat dijadikan minyak pala. Daging buah pala dimanfaatkan untuk olahan manisan pala, asinan pala, dodol pala, serai pala, dan syrup pala, pemanfaatan lainnya adalah seagai bahan campuran pada minuman, antimikrobia atau bioinsektisida (NURJANNAH, 2007). Di Cina dan India minyak pala dimanfaatkan untuk pengobatan atau kesehatan manusia yaitu stimulus sistem jantung, pencernaan, diare, rematik, nyeri otot, atuk, pernafasan, tekanan darah, sakit gigi, penghilang racun pada hati (erowid, 2001; ANONIM,
2008; dalam BUSTAMAN, 2008). Tanaman pala menghasilkan senyawa miristisin. Pala merupakan tanaman rempah yang menghasilkan minyak atsiri dan lemak khusus yang berasal dari biji dan fuli. Biji pala menghasilkan minyak atsiri 2-5 \% dan 30-40 \% minyak lemak sedangkan fuli menghasilkan $7-18 \%$ minyak atsiri dan 20-30 \% lemak. Menurut standar Internasional (ISO, 2002) minyak pala dihasilkan dari penyulingan biji pala jenis Myristica fragrans atau dikenal sebagai Pala Banda. Jenis pala tersebut banyak dibudidayakan dan diolah di daerah Maluku,Sulawesi Utara Aceh dan Pulau Jawa (RUSLI, 2002). Dalam perdagangan dunia dikenal 2 jenis biji pala yaitu jenis East Indian berasal dari Indonesia dan Sri Langka, jenis ini disebut jenis superior dan West Indian, yang berasal dari Granada (LAWLESS, 2002)

Dalam biji pala yang sudah tua disamping menghasilkan minyak atsiri 
terdapat minyak komponen yang bersifat tidak menguap yang disebut fixed oil atau mentega pala.Menurut Leung(1985) fixed oil adalah bahanbahan yang larut dalam pelarut organik, tetapi tidak dapat didestilasi.Menurut Devi(2009) biji pala mengandung fixed oil sebesar sebesar $20-40 \%$ yang tersusun dari asam miristat, trimiristin dan gliserida dari asam laurat,stearat dan palmitat.Telah dilakukan isolasi trimiristin dari biji pala dari sisa penyulingan biji pala,rendemen yang trimiristin yang dihasilkan adalah sebesar $21,60 \%$ dengan kemurnian $89,86 \%$. Trimiristin adalah jenis lemak yang banyak digunakan dalam industri kosmetik sebagai pemutih. Kandungan minyak atsiri pala meliputi $\alpha$-Pinene, $\alpha$ Phellandrene, Sabinene,cyclobutane, safrene, $\mathrm{Y}$ Terpinene, Myrcene, Myristiin.

Pada penelitian ini dilakukan isolasi minyak atsiri pada biji pala yaitu dengan metode isolasi yang dilakukan yaitu distilasi uap,serta menganalisis komponen. Komponen kimia pada minyak pala baik secara kualitatif maupun kuantitatif dengan menggunakan alat GC-MS.

\section{METODE PENELITIAN}

Alat

Alat-alat yang digunakan adalah seperangkat alat distilasi,Pendingin bola, Penangkap minyak, Hot Plate, Spektrometer GC-MS Shimadzu.

\section{Bahan}

Serbuk biji Pala, Aquades, $\mathrm{Na}_{2} \mathrm{SO}_{4}$ anHidrous p.a

\section{Prosedur \\ Isolasi Minyak Biji Pala dengan Metode Destilasi Uap}

Isolasi minyak bii pala yang dilakukan adalah serbuk sampel yang telah ditimbang dimasukkan ke dalam labu destilasi dan ditambahkan akuades.
Peralatan destilasi dipasang dan dipanaskan. Proses distilasi dilakukan selama dua jam setelah mendidih. Tampung destilat yang diperoleh.Uap air yang berisi campuran minyak dan air dipisahkan dengan corong pemisah untuk diambil minyak pala.Minyak pala yang diperoleh selanjutnya dimurnikan dengan menambahkan $\mathrm{Na}_{2} \mathrm{SO}_{4}$ an Hidrous. Sampel kemudian digojog gojog sehingga diperoleh minyak berwarna kuning jernih dan bebas air.

\section{Identifikasi Komposisi Minyak Pala dengan GC-MS}

Untuk mengetahui komponen-komponen senyawa hasil isolasi minyak biji pala dilakukan dengan membandingkan pola fragmen spektra GC dengan pola fragmentasi spektra MS yang telah diketahui strukturnya yang berasal dari data base komputer yang telah dihubungkan dengan alat GC-MS.

\section{HASIL DAN PEMBAHASAN}

Pada proses destilasi uap adalah metoda destilasi yang merupakan kodistilasi campuran air dan senyawa organik volatil yang tidak bercampur dengan air. Destilasi uap sering digunakan untuk memisahkan senyawa volatil dan senyawa non volatil.Pemilihan metode destilasi ini karena metode ini baik untuk menyuling bahan atau sampel yang berbentuk serbuk dan bunga-bungaan yang mudah menggumpal jika terkena panas. Proses destilasi dilakukan selama 2 jam setelah mendidih. Komponen- komponen senyawa atsiri pada sampel akan teruapkan dari jaringan bersama-sama uap air. Setelah uap minyak dan uap air melalui kondensor, uap akan mengembun berubah menjadi cairan distilat dan ditampung. Pada distilat ini minyak pada posisi diatas air karena berat jenis minyak lebih rendah dari air. Fraksi air dan minyak dipisahkan 


\section{R. Astuti/ Vol 1 (2) 2019, 36-40}

dengan corong pemisah. Untuk menghilangkan kemungkinan masih ada sisa air pada minyak maka ditambahkan $\mathrm{Na}_{2} \mathrm{SO}_{4}$ an hidrous secukupnya. Minyak atsiri biji pala yang dihasilkan pada penelitian ini sebanyak $2 \mathrm{~g}$ dari sampel kering sebanyak 100,02 g. Rendemen minyak atsiri yang dihasilkan adalah 2 $\%$.

\section{Identifikasi Komposisi Kimia Minyak} Biji Pala.

Untuk mengetahui komponen kimiawi dari minyak pala, dilakukan

Tabel 1. Daftar komposisi senyawa hasil isolasi biji Pala analisis menggunakan metode GC-MS Hasil isolasi minyak biji pala adalah senyawa yang mudah menguap (volatil) sehingga dapat dianalisis dengan GCMS.Hasil analisa GC-MS menunjukkan 17 puncak yang berarti 17 komponen senyawa pada minyak biji pala pada hasil isolasi. Ketujuh belas kompnen senyawa tersebut selanjutnya diidentifikasi memakai spektroskopi massa.

\begin{tabular}{|c|c|c|c|}
\hline Puncak & $\begin{array}{l}\text { Nama } \\
\text { Senyawa }\end{array}$ & Waktu retensi & $\begin{array}{l}\% \text { Luas } \\
\text { puncak }\end{array}$ \\
\hline 1. & $\alpha$-Phellandrene & 10,147 & 1,90 \\
\hline 2. & $\alpha$-Pinene & 10,436 & 3,10 \\
\hline 3. & Sabinene & 12,030 & 22,53 \\
\hline 4. & $\beta$-Pinene & 12,165 & 1,66 \\
\hline 5. & Myrcene & 12,570 & 1,87 \\
\hline 6. & $\alpha$-Phellandrene & 13,202 & 1,22 \\
\hline 7. & 1,3Cyclohexadiene & 13,611 & 2,43 \\
\hline 8. & Benzene & 13,916 & 1,60 \\
\hline 9. & Limonene & 14,162 & 19,71 \\
\hline 10. & $\mathrm{y}$-Terpinene & 15,147 & 4,22 \\
\hline 11. & a-Terpinolene & 16,093 & 0,94 \\
\hline 12. & Terpineol-4 & 19,472 & 15,14 \\
\hline 13. & Piperifone & 21,699 & 0,28 \\
\hline 14. & 1,3-Benzodioxole & 22,923 & 20,50 \\
\hline 15. & Benzene & 25,879 & 1,39 \\
\hline 16. & Myristcin & 29,200 & 0,95 \\
\hline 17. & Elemicin & 29,752 & 0,56 \\
\hline
\end{tabular}

Dari Tabel 1. Dari analisis dengan GC dapat diketahui bahwa terdapat lima senyawa dengan \% Area terbanyak adalah Sabinene (22\%);Benzodioxole $(20,50 \%)$;Limonene $(19,71 \%)$ Terpineol4(15,14\%); $\gamma$-Terpinene (4,22\%); dan $\alpha$ Pinene $(3,10 \%)$ dan senyawa Myristcin ada di R.Time 29,200 dengan 0,95\% luas puncak.

Kondisi operasional dari instrumen Kromatografi gas sebagai berikut:

Merk Alat :GCMS-QP2010S SIMADZU

$\begin{array}{lc}\text { Kolom } & : \text { Rtx } 5 \mathrm{MS} \\ \text { Panjang } & : 30 \text { meter } \\ \text { ID } & : 0,25 \mathrm{~mm} \\ \text { Film } & : 0,25 \mathrm{um} \\ \text { Gas pembawa } & : \text { Helium } \\ \text { Pengionan } & : \text { El } 70 \mathrm{Ev} \\ \text { Column Oven Temp. } & : 70^{\circ} \mathrm{C} \\ \text { Inject.Temp. } & : 300,00^{\circ} \mathrm{C} \\ \text { Inject.Mode } & : \text { Splitless } \\ \text { Sampling Time } & : 1.00 \mathrm{~min} \\ \text { Flow Control Mode } & : \text { Pressure } \\ \text { Pressure } & : 12.0 \mathrm{kPa} \\ \text { Total Flow } & : 27.3 \mathrm{ml} / \mathrm{min}\end{array}$




$\begin{array}{llll}\text { Column Flow } & : 0.49 \mathrm{ml} / \mathrm{min} & \text { Split Ratio } & : 49.0 \\ \text { Linear Velocity } & : 25.5 \mathrm{~cm} / \mathrm{sec} & \text { High Pressure Inject. } & : \text { OFF } \\ \text { Purge Flow } & : 3.0 \mathrm{ml} / \mathrm{min} & \text { Carrier Gas Saver } & : \text { OFF }\end{array}$

Tabel 2. Oven Temp. Program

\begin{tabular}{ccc}
\hline Rate & Temperature $\left({ }^{\circ} \mathrm{C}\right)$ & Hold Time $(\min )$ \\
\hline- & 70.0 & 5.00 \\
5.00 & 300.0 & 19.00
\end{tabular}
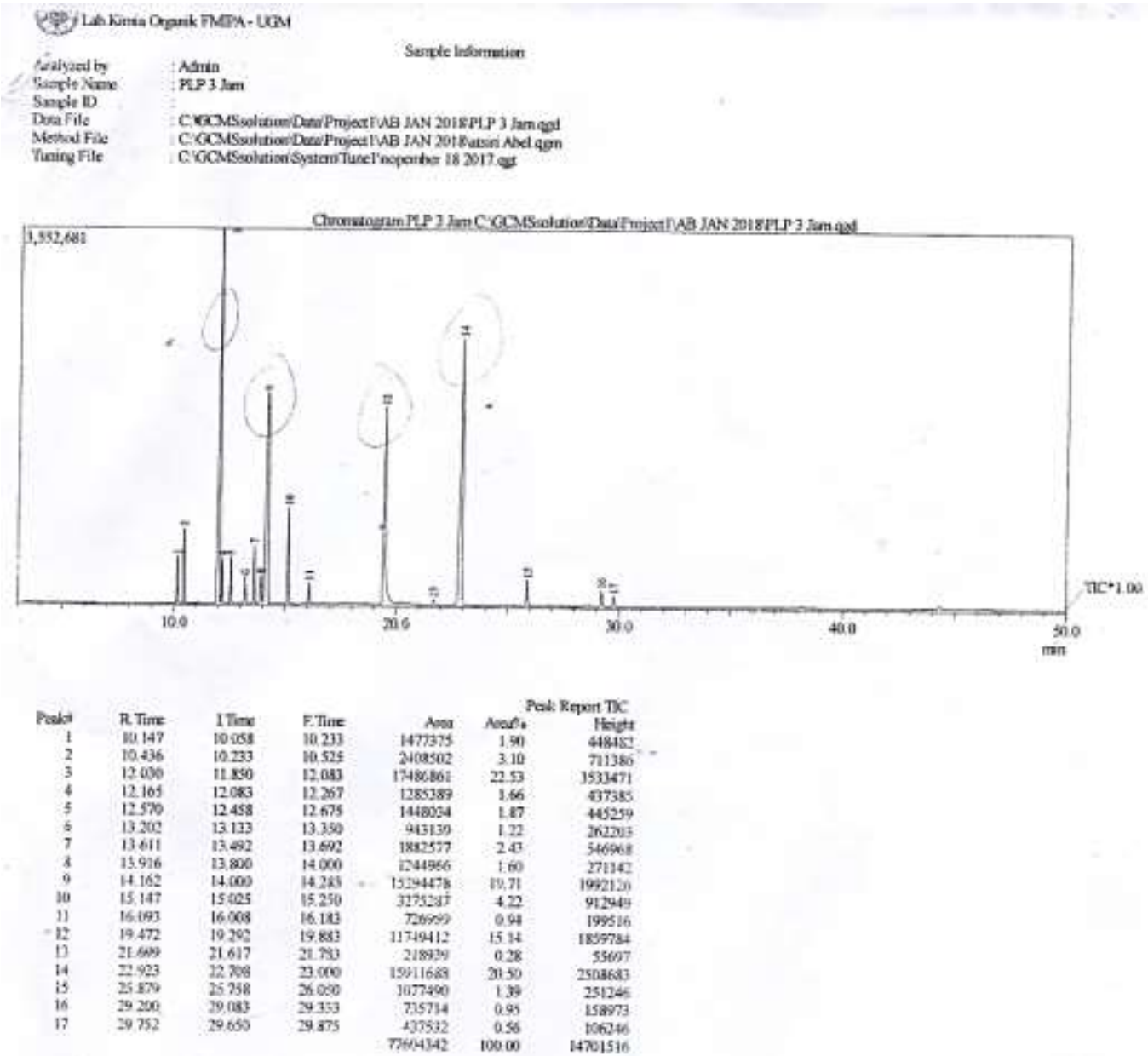

Gambar 1. Hasil pengujian kromatografi

\section{KESIMPULAN}

Dari hasil penelitian isolasi biji pala (Myristica fragrans ) dengan distilasi uap dihasilkan minyak biji pala yang berwarna kuning jernih. Hasil isolasi kemudian di identifikasi komponen senyawanya dengan instrumen GC MS.Komponen senyawa yang teridentifikasi adalah sebagai berikut :Sabinene (22\%) se, Benzodioxole (20,50); Limonene(19,71); Terppertiineol-4 (15,14\%); $\mathrm{Y}$-Terpinene $(4,22 \%) ; \quad \alpha$-pinene $(3,10 \%) ; \quad \beta$-pinene $(1,6 \%) ; \quad$ Myrcene $\quad(1,87 \%) ;$ aPhellandrene (1,22\%); Cyclohexane $(1,60 \%)$; Benzena (1,39\%); $\alpha$ Terpinolene $\quad(0,95 \%) ; \quad$ Piperifone $(0,28 \%)$; dan Myristicin (0,95\%). Untuk 
penelitian selanjutnya agar dilakukan analisis Sifat-sifat Fisika minyak atsiri biji pala yaitu meliputi berat jenis,indek bias,titik leleh,warna dan bau.

\section{UCAPAN TERIMA KASIH}

Ucapan terima kasih disampaikan kepada Direktorat Sumber Daya Manusia (SDM) UGM,Tim Dosen Pengampu dari Departemen TPHP FTP UGM atas kesempatan dan segala fasilitas yang telah diberikan kepada penulis.

\section{DAFTAR PUSTAKA}

ANONYMOUS, $2010^{\mathrm{a}}$. Trimyristin from Nutmeg. http://www.scribd.com/ doc/ $92996 \quad 719 /$

Lab5Extraction3Trymiristin from Nutmeg FS2010 [26Juli 2018].

Devi,P. 2009.The Compound maceligan isolated from Myristica fragrans. European Journal of Pharmacy Research. 2(11):1669-1675.

Djatmiko, B.1986. Teknologi Lemak dan Minyak. Balai Pustaka,Jakarta . P20-40.

ISO 3215. 2002. Oil of Nutmeg. International Standart Organization. 8 p.

Ketaren, Pengantar Teknologi Minyak Atsiri. Balai Pustaka.458 hal.

Leung,A. 1985. Encyclopedia of Natural Ingredients. John Willey and son. 